\title{
Molecular aspects of enzyme synthesis in the exocrine pancreas with emphasis on development and nutritional regulation
}

\author{
BY ISABELLE LE HUEROU-LURON ${ }^{1}$, EVELYNE LHOSTE ${ }^{2}$, \\ CATHERINE WICKER-PLANQUART ${ }^{3}$, NADIA DAKKA ${ }^{3}$, \\ RENÉ TOULLEC ${ }^{1}$, TRISTAN CORRING ${ }^{2}$, PAUL GUILLOTEAU ${ }^{1}$ \\ AND ANTOINE PUIGSERVER ${ }^{3}$ \\ ${ }^{1}$ Laboratoire du Jeune Ruminant, INRA, 65 rue de Saint Brieuc, 35042 Rennes Cédex, France, \\ ${ }^{2}$ Laboratoire d'Ecologie et de Physiologie du Système Digestif CRJ, INRA, Jouy-en-Josas, France \\ and ${ }^{3}$ Centre de Biochimie et de Biologie Moléculaire, CNRS, Marseille, France
}

At least twenty secretory proteins are synthesized in the exocrine pancreas of higher vertebrates, most of which are essential enzymes for digestion to be carried out. Using two-dimensional polyacrylamide-gel electrophoresis in sodium dodecyl sulphate, it has been possible to identify in the rat two isozymes of amylase $(E C 3.2 .1 .1)$, the main protein $(20 \%)$ present in the pancreatic secretion, a single form of lipase ( $E C$ 3.1.1.3), colipase, phospholipase $\mathrm{A}_{2}$ (EC 3.1.1.4), ribonuclease $(E C$ 3.1.27.5) and deoxyribonuclease ( $E C$ 3.1.21.1), and several forms of proteases, including endopeptidases (serine proteases) and exopeptidases (metalloproteases). The serine protease family, which accounts for as much as $44 \%$ of the total protein synthesis, is by far the most complex and includes a cationic and three anionic forms of trypsin (EC 3.4.21.4), as well as two or three chymotrypsins ( $E C$ 3.4.21.1, $E C$ 3.4.21.2) and two elastases ( $E C$ 3.4.21.36) with a cationic and one or two anionic isozymes in each case, and several kallikrein-like proteins. All these serine proteases have comparable molecular mass values, similar structures and catalytic functions, but quite different substrate specificities. Among the metalloproteases, two isozymic forms of carboxypeptidase $\mathrm{A}$ (EC 3.4.17.1) and a single form of carboxypeptidase $\mathrm{B}(E C$ 3.4.17.2) have been identified. It is worth mentioning here that the zymogen of carboxypeptidase $\mathrm{A}$ is characterized by its ability to complex with one or two other proteins in the pancreatic acinar cell, mostly in ruminant species but also in pigs and humans. In bovine pancreatic tissue, procarboxypeptidase A mainly occurs as a ternary complex in which the zymogen itself is non-covalently associated with chymotrypsinogen $\mathrm{C}$ and the so-called subunit III which has recently been found to derive from proproteinase $\mathrm{E}$ via an autolytic transformation (Pascual et al. 1990).

The nucleotide sequences of the cDNA clones and/or genes encoding a given pancreatic secretory enzyme in a number of mammals or encoding isozymes in a single mammalian species have shown a fairly high degree of structural similarity among the cloned messengers. The extent of similarity between bovine anionic trypsinogen mRNA, for instance, and rat anionic and rat cationic trypsinogen mRNA is $81-84$ and $75 \%$ respectively, whereas the similarity in amino acid sequence between the anionic and cationic forms of bovine trypsinogen $(65 \%)$ is lower than that existing between the bovine anionic protein and other mammalian anionic trypsinogens (73-85\%; MacDonald et al. 1982a; Le Huërou et al. 1990a). In the same way, there exists a high degree of similarity between the nucleotide sequences $(81 \%)$, on the one hand, and the amino acid sequences $(78-80 \%)$, on the other hand, of bovine preprocarboxypeptidase $A$ and rat preprocarboxypeptidase A1 (Clauser et al. 1988; Gardell et al. 1988; Le Huërou et al. 
1991). An $85 \%$ structural similarity was recorded between rat and porcine elastase $I$, but only $60 \%$ similarity between these two amino acid sequences and both human and rat elastase II (MacDonald et al. 1982b; Kawashima et al. 1987). The comparison between the rat lipase and colipase amino acid sequences, as deduced from the corresponding nucleotide sequences, and those of other mammalian species also indicated a fairly high degree of structural similarity (75-88 and 60-69\% respectively). However, a much higher level of similarity was found to exist between the lipase sequences of several species than between the isolipase sequences of the rat $(74 \%$; Wicker \& Puigserver, 1990a; Wicker-Planquart \& Puigserver, 1992). Therefore, it can be concluded that the structural similarity observed between species reflected the conservation of the genome despite the existence of some evolutionary divergence.

Site-directed mutagenesis experiments undoubtedly need to be performed to find out whether or not the structural changes observed in the nucleotide sequences of cloned isozyme mRNA might also reflect modifications in the corresponding genes, which might explain the observed regulation of isozyme expression. A high degree of similarity is known to exist in the 5'-non-coding segments of the rat, dog and cow anionic trypsins, and identical stretches six nucleotides in length were found to be highly complementary to the $3^{\prime}$ end of $18 \mathrm{~S}$ rRNA. This was expected to favour the interaction between anionic trypsinogen mRNA and $40 S$ ribosomal subunit leading to an increased translational efficiency of the anionic isozymes as compared with the cationic isozymes (MacDonald et al. 1982a; Pinsky et al. 1985; Kern et al. 1987). Comparison between the 5'-flanking regions of nine genes expressed in both the rat and mouse exocrine pancreas resulted in the identification of a family of short, related sequences located within the enhancer regions of these genes (Walker et al. 1983; Swift et al. 1984; Boulet et al. 1986; Stevenson et al. 1986; Howard et al. 1989). Site-directed mutagenesis studies showed that these cis-acting sequences are actually involved in regulating the expression of tissue-specific genes through the binding of the specific pancreatic nuclear protein PTF1.

The mechanisms which are involved in the induction or repression of the expression of specific enzymes in pancreatic cells are still partly unknown. Amylase expression has been the most extensively studied since it is completely inhibited in diabetes and induced by insulin. An insulin-dependent element (IDE) has been identified upstream of the PTF1-binding sequence in the amylase gene (Keller et al. 1990). The binding of a trans-acting repressor to amylase-specific sequences within the IDE which are adjacent to the PTF1 site might prevent gene activation by PTF1 and, therefore, inhibit amylase expression in the pancreas. Close to IDE, the amylase gene shares a common sequence with the fos gene. This sequence is known to bind the serum response factor, a protein which influences the insulin-induced expression of fos. Hybrid constructs in transgenic mice have been performed in order to define a DNA sequence in the 5'-flanking region of the amylase gene which was taken to be a functional dietary response unit (Schmid \& Meisler, 1992). This fragment included two previously described regulatory elements, IDE and a pancreatic enhancer. Very little is known about the specific regulation of other genes; using a pancreatic cancer cell line (AR4-2J), Stratowa \& Rutter (1986) have shown, however, that $\mathrm{Ca}$ induces trypsinogen expression and inhibits that of chymotrypsinogen and amylase. Further structural analysis of the mRNA and genes coding for digestive enzymes from various species is necessary to gain a better understanding of the mechanisms underlying pancreatic adaptation to nutritional substrates as well as during ontogenesis. 


\section{ONTOGENIC CHANGES}

\section{Embryogenesis}

The pattern of digestive enzymes from the exocrine pancreas is known to change considerably during both the embryonic and neonatal periods, as well as at weaning which is generally taken to involve considerable modulation of several enzyme levels. The synthesis and accumulation of secretory proteins during embryogenesis in the rat is known to include at least three distinguishable phases, presumably reflecting distinct regulatory transitions (Rutter et al. 1968; Pictet et al. 1972; Harding et al. 1977; Van Nest et al. 1980; Han et al. 1986). In the course of the early period which is known as the predifferentiated state (day 11 of gestation), the pancreatic bud emerges as a diverticulum of the embryonic foregut and no enzymic activity is detectable. The next protodifferentiated state (between days 12 and 14 of gestation) is characterized by histological differentiation, without any obvious cytodifferentiation, and the presence of low, but significant levels of zymogens and enzymes in the exocrine pancreatic rudiment. Subsequently, during the differentiated embryonic state (between day 15 of gestation and term), an extensive cytodifferentiation occurs, which is characterized by an increase in the volume of the organelles involved in secretory protein processing including the development of zymogen granules and resulting in the considerable accumulation of specific zymogens.

Significant amounts of specific pancreatic mRNA are detected during the protodifferentiated state, while larger changes in gene expression occur during the late embryonic phase. The changes in mRNA levels exceed 10000 -fold and qualitative and quantitative differences have been observed in the expression patterns of each gene. The control of gene expression during embryogenesis primarily involves regulation at the transcriptional level and to a lesser extent, at the translational level. Multiple regulatory elements, termed trans-acting differentiators (Han et al. 1986), might interact with the gene to control the transcription process. Related sequences in the $5^{\prime}$-flanking regions of nine pancreatic exocrine genes were found to be located within the enhancer regions and might play a role in the regulation of cell-specific expression (Walker et al. 1983; Swift et al. 1984; Boulet et al. 1986).

In the bovine foetus at $60-70 \mathrm{~d}$ of gestation, the pancreas already possesses the characteristics of the differentiated state as observed in the rat foetus (Track et al. 1972). However, no studies have been carried out so far at an earlier period in this species or on pancreatic enzymic expression in the pig embryo.

\section{Postnatal development}

The enzyme-specific activities in rat pancreas are maximal at birth, decrease rapidly to very low levels during the first week of life and stay unchanged until the weaning period which usually starts on day 14 and is completed on day 21 (Corring \& Aumaitre, 1970; Robberecht et al. 1971; Saraux \& Girard-Globa, 1982). From day 21 onwards, all the specific activities increase up to the adult levels which are nevertheless lower than those at birth. At the same time, the maturation of pancreatic cells is accompanied by changes in the concentrations of several mRNA (Iovanna et al. 1990). Both the amylase and chymotrypsinogen B mRNA concentrations decrease during the suckling period and increase during the weaning period. After day 20 , the chymotrypsinogen B mRNA level 
is stable while that of amylase continues to increase until day 87 . The relatively parallel changes in the enzyme activities and the corresponding mRNA which have been observed during the first 3 weeks of life, therefore, mainly reflect a pretranslational modulation of gene expression. This control of the synthesis of pancreatic proteins might be exerted by a number of hormones such as corticosterone and thyroxine, the concentrations of which increase during the second and third postnatal weeks (Henning, 1987). During normal development, the level of amylase parallels that of corticosterone in the rat serum (Takeuchi et al. 1977), and glucocorticoids were found to induce the transcription of amylase gene in both hepatoma cells (Samuelson et al. 1988) and the AR4-2J cell line (Logsdon et al. 1987). A DNA sequence able to interact with the glucocorticoid receptor has been located in the promoter region of both amylase 1 and 2 genes (Osborn et al. 1987). Other regulatory elements involved in the response to nutritional changes might also influence gene expression. Before birth, nourishment takes place through the placenta, whereas during the first 2 weeks of life it depends entirely on lactation and subsequently on food ingestion. Nutrients are potent stimuli that trigger several changes in pancreatic mRNA and enzyme activities, as depicted later when nutritional adaptation will be discussed.

In milk-fed calves, most of the pancreatic enzymes (except amylase) are present at birth and their levels rapidly decrease during the first $2 \cdot \mathrm{d}$ of life (Le Huërou-Luron et al. 1992). Afterwards, the specific enzymic activities increase with age in the case of chymotrypsin, elastase, carboxypeptidase B, ribonuclease, lipase and amylase, decrease in the case of trypsin and colipase, and remain unchanged in the case of carboxypeptidase $A$ and phospholipase $A_{2}$ (Fig. 1). During the same time, the specific mRNA encoding amylase, lipase and trypsin increase, while chymotrypsin mRNA decreases to a minimum value on the 28 th day and further increases to approximately the newborn level on the 119th day (Le Huërou et al. 1990b). The non-parallel variations in the mRNA and enzyme activity levels during postnatal development probably result from a multiplelevel (pretranslational and translational) control of gene expression. At weaning, marked anatomical and physiological changes occur in calves due to the development of forestomachs (rumen) and microbial digestion (Ruckebusch et al. 1983). Most enzyme activities are higher in weaned animals than in milk-fed animals (Le Huërou-Luron et al. 1992) and the corresponding mRNA also increase (Le Huërou et al. 1990b). The parallel enhancement of both the enzyme activities and their specific mRNA observed at weaning is consistent with the involvement of pretranslational control of the corresponding genes. However, the factors which may influence the levels of translatable mRNA are still unknown and consequently nutritional and hormonal regulation might take place together. For example, both secretin and cholecystokinin (CCK) increase the overall protein secretion, particularly that of amylase, in preruminant calves (Davicco et al. 1980). The ability of the pancreatic secretory system to respond to gastrointestinal hormones and peptides is not only correlated to the appearance of the endogenous gut regulatory peptides during the neonatal period (Guilloteau et al. 1992), but also to the development of the intracellular processes involved in stimulus-secretion coupling, e.g. receptors, intracellular second messengers, etc. The binding capacity and the affinity of pancreatic receptors for the vasoactive intestinal peptide/secretin and CCK/gastrin families evolve for example during postnatal development and weaning in calves (Le Meuth et al. 1991, 1992). Furthermore, a differential expression of A- and B-subtype CCK/gastrin receptors was observed during development (Le Meuth et al. 1992). In 
(A)

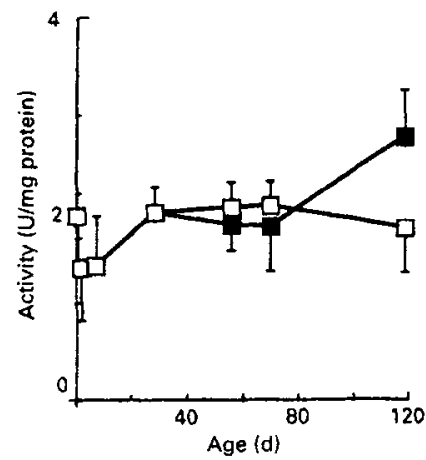

(B)

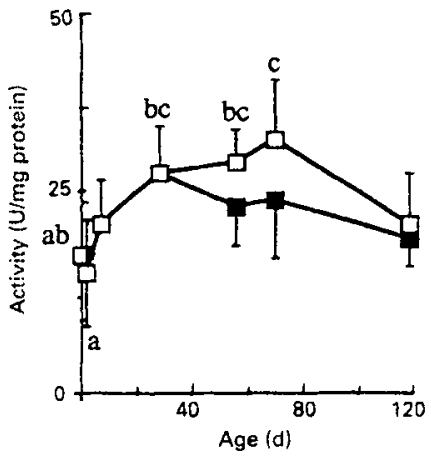

(C)

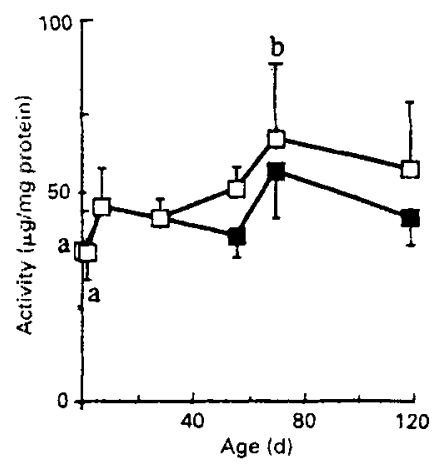

(D)

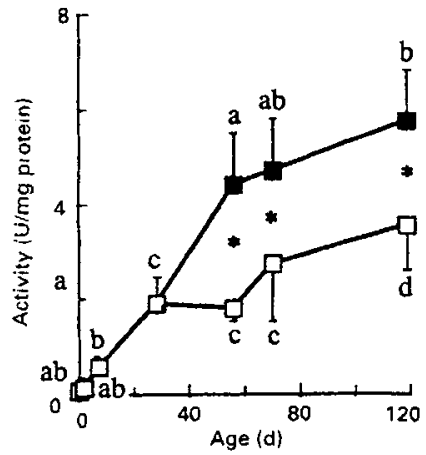

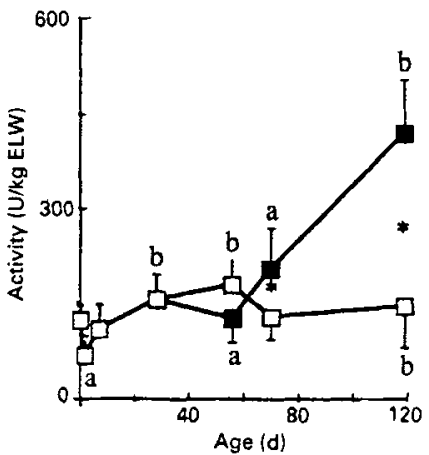
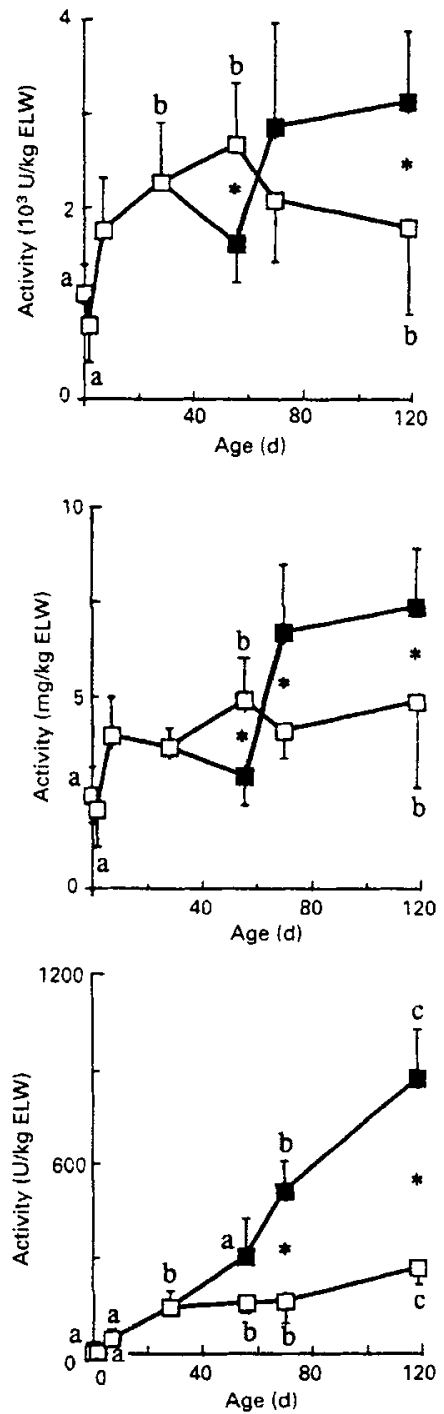

Fig. 1. Changes in the activities (per mg protein and $\mathrm{kg} E L W)$ of (A), carboxypeptidase $\mathrm{A}(E C$ 3.4.17.1), (B), carboxypeptidase $\mathrm{B}(E C$ 3.4.17.2), (C), ribonuclease (EC 3.1.27.5) and (D), amylase (EC 3.2.1.1) during development and after weaning. $(\square)$, Preruminants; ( $\square)$, ruminants. Values are means with their standard errors for five animals. ELW, empty live weight. a, b, c, Within each group, values with unlike superscript letters are significantly different $(P \leq 0 \cdot 05)$. Mean values for preruminant animals were significantly different from those for ruminants: ${ }^{*} P \leq 0.05$. 
newborn pigs, chymotrypsin and trypsin activities are present and increase at different rates throughout the suckling period (Pond et al. 1971; Corring et al. 1978). After weaning, the pancreatic secretion increases significantly and the qualitative composition of the juice changes markedly (Pierzynowski et al. 1990). However, no studies have been performed up to now on the molecular mechanism involved in this developmental process.

\section{NUTRITIONAL ADAPTATION}

It is well known that the levels of pancreatic hydrolases are regulated by the composition of the diet (Ben Abdeljlil \& Desnuelle, 1964; Reboud et al. 1966; Corring, 1977; Poort \& Poort, 1981). As a general rule, changes in the pancreatic enzyme content occur as early as the first $24 \mathrm{~h}$ after a dietary change and continue until days 5-7, when steady-state levels are reached. The mechanisms whereby dietary components alter the expression of specific enzymes occur at the gene level (transcription), the mRNA level (processing, extranuclear transport, cytoplasmic stability or translation efficiency), and the protein stability level. The possible mediators of nutritional adaptation are manifold: gut regulatory peptides released in response to the presence in the lumen of nutrients or hydrolysis products from dietary substrates and subsequent metabolites, or even absorbed circulating plasma metabolites.

Pancreatic adaptation to dietary proteins, carbohydrates and fat has been widely investigated in various species (for recent reviews, see Corring et al. 1989; Brannon, 1990). Although the molecular aspects of the pancreatic response to nutritional substrates are currently being investigated in both rats and pigs, only the most recent findings obtained with rats will now be discussed.

\section{Proteins and carbohydrates}

The specific activities (Ben Abdeljlil et al. 1963) and synthesis (Reboud et al. 1964) of pancreatic proteases and amylase were found to be regulated in direct proportion to the level of protein and carbohydrate substrates in the diet respectively. Similar effects on enzyme activities were also observed when dietary proteins or starch were replaced by a protein hydrolysate (Johnson et al. 1977; Temler et al. 1984) or glucose (Howard \& Yudkin, 1963; Deschodt-Lanckman et al. 1971; Robberecht et al. 1971). By contrast, either oral or intravenous infusion of amino acids did not affect the protease activities while that of amylase was changed in response to intravenous infusion of glucose (Lavau et al. 1974). The increase in amylase activity paralleled the level of dietary carbohydrate at the expense of dietary fat or protein. With high-protein or high-carbohydrate diets, the fact that the levels of amylase and serine proteases in pancreatic lobules were directly correlated with those of the corresponding mRNA indicates that the synthesis of these proteins may be mostly regulated at the pretranslational level (Table 1; Wicker et al. 1983, 1984; Giorgi et al. 1984, 1985). By contrast, both the synthesis and mRNA levels of procarboxypeptidases and lipase remained unchanged under the same dietary manipulations. The changes observed in the stability of trypsinogen and proelastase mRNA in response to a high-protein diet suggest that post-transcriptional regulation by the diet may also have occurred, whereas the half-lives of the mRNA specific to amylase and the other serine proteases showed no change (Puigserver et al. 1986). 
Table 1. mRNA levels of pancreatic hydrolases estimated by in vitro translation in a cell-free system as influenced by the protein-carbohydrate content of the diet*

\begin{tabular}{lllll}
\hline \hline & \multicolumn{4}{c}{ Exocrine proteins (\% radioactivity) } \\
\cline { 2 - 5 } & A & B & C & D \\
Diet . . & & & & \\
\hline Enzymes & 15 & 16 & 16 & 17 \\
Lipase (EC 3.1.1.3) & 22 & 23 & 23 & 21 \\
Procarboxypeptidases & 27 & 20 & 15 & 13 \\
Amylase & 36 & 42 & 46 & 50 \\
Serine proteases & & & & \\
\hline \hline
\end{tabular}

* The protein and carbohydrate levels respectively were (g/kg): A 230, 580; B 440, 370; C 640, 170; D 810, 0 .

Chymotrypsin (but not trypsin) secretory output in the pig was found to increase only a few hours after a single high-protein meal, and the maximum response was reached after 5-7 d of nutritional adaptation. After feeding on a high-protein diet for $7 \mathrm{~d}$, the amylase and lipase specific activities decreased while those of trypsin, chymotrypsin, elastase and carboxypeptidase A increased. However, the mRNA levels were only discretely modulated when the high-protein diet was fed for 3-8 d (Lhoste et al. 1993). In pigs fed on 70 or $480 \mathrm{~g}$ protein $/ \mathrm{kg}$ diets for $4 \mathrm{~d}$, a good correlation was observed between the amylase activity level, its specific biosynthesis in pancreatic lobules and the mRNA translation level in vitro. With regard to serine proteases, the biosynthesis paralleled the enzyme activities, although with somewhat lower values. Assuming that chymotrypsinogens are the main form of serine proteases in the pig, their nutritional regulation might be, at least partly, transcriptional since after feeding on a $480 \mathrm{~g}$ protein $/ \mathrm{kg}$ diet for $3 \mathrm{~d}$, the chymotrypsinogen mRNA also increased. Since this effect was no longer observed after a 6 or $8 \mathrm{~d}$ feeding period, the transcription may have been first transiently modified and translational regulation may have taken place thereafter.

The response of rat pancreatic enzymes to the severe protein malnutrition induced by a protein-free carbohydrate-rich $(810 \mathrm{~g} / \mathrm{kg})$ diet did not seem to correspond to any classical scheme of pancreatic adaptation to nutritional factors. The tissue activity levels of trypsinogen in the rat, that of lipase in the pig and those of chymotrypsinogen and amylase in both species decreased with a protein-free diet (Snook, 1965; Corring et al. 1984). The adaptation pattern of serine proteases was biphasic and consisted of a severe decrease in the enzyme activities during the first $2 \mathrm{~d}$ of protein deprivation followed by a variably pronounced increase. However, the final enzyme activity levels were always significantly lower than those reported with a normal-protein diet (Dakka et al. 1988). The protein-free carbohydrate-rich diet was associated with decreased amylase synthesis and that of the cationic isozymic forms of serine proteases, and surprisingly there was an increase in that of the anionic forms (Schick et al. 1984; Dakka et al. 1988). The decrease in the activity and synthesis of most enzymes during protein deprivation might reflect the limited availability of essential amino acids, whereas the paradoxical increase in the anionic protease isozymes was interpreted as possibly being a protective mechanism ensuring that proteases are available to digest any consumed or endogenous protein (Schick et al. 1984). The protein-free carbohydrate-rich diet was also found to increase the levels of chymotrypsin and amylase mRNA (Dakka et al. 1988) as well as those of 
Table 2. Transcription rates normalized to that of actin of rat pancreatic amylase, chymotrypsin and trypsin genes as influenced by a protein-free carbohydrate-rich diet

(Mean values with their standard errors)

\begin{tabular}{|c|c|c|c|c|c|c|c|}
\hline \multirow{3}{*}{$\begin{array}{l}\text { Consumption } \\
\text { period (d) }\end{array}$} & \multicolumn{7}{|c|}{ Relative transcription rates } \\
\hline & \multirow[b]{2}{*}{ Actin } & \multicolumn{2}{|c|}{ Amylase } & \multicolumn{2}{|c|}{ Chymotrypsin } & \multicolumn{2}{|c|}{ Trypsin } \\
\hline & & Mean & $\mathrm{SE}$ & Mean & SE & Mean & $\mathrm{SE}$ \\
\hline 0 & 1 & $3 \cdot 2$ & $0 \cdot 3$ & $2 \cdot 0$ & 0.5 & $2 \cdot 4$ & 0.8 \\
\hline 1 & 1 & $3 \cdot 2$ & 0.2 & $2 \cdot 7$ & 0.5 & $3 \cdot 3$ & 0.6 \\
\hline 3 & 1 & $3 \cdot 5$ & $0 \cdot 6$ & $3 \cdot 8$ & 0.9 & 3.9 & $0 \cdot 3$ \\
\hline
\end{tabular}

anionic trypsin I and II and cationic trypsin mRNA, while no changes in the mRNA specific to anionic elastase I and cationic elastase II were observed (Dakka et al. 1990). Therefore, the accumulation of amylase, chymotrypsin and anionic trypsin mRNA probably resulted from stimulation of transcription (Table 2) and/or increase in mRNA stability while the opposite response of the corresponding specific activities, and in some cases of the synthesis, reflected a translational control. The fact that elastase expression was only translationally regulated might explain the changes observed in the biosynthesis and specific activities.

\section{Lipids}

The adaptation of lipase resembles that of amylase but not that of proteases, since the oral or intravenous administration of fat digestion endproducts changes the lipase activity as effectively as the ingestion of the intact substrates (for review, see Brannon, 1990). The intensity of the adaptive response was found to depend on the animal species, on the percentage of energy provided by dietary fat (Wicker \& Puigserver, 1987) and on the type of fat, since unsaturated lipids stimulated the lipase activity more efficiently than saturated lipids (Robberecht et al. 1971; Bazin et al. 1978; Sabb et al. 1986; Simoes Nunes, 1986). However, pancreatic lipase responded to dietary fat when the fat content was increased at the expense of dietary protein or carbohydrate, indicating that the primary effector is the dietary fat. Conflicting results have been obtained on the possible effects of dietary lipids on modulating colipase activity (Girard-Globa \& Simond-Cote, 1977; Vandermeers-Piret et al. 1977; Mourot \& Corring, 1979). The observed nutritional adaptive process seemed to occur in the rat only when the daily protein intake was between 3.5 and $6.5 \mathrm{~g}$ (Saraux et al. 1982). The increase in lipase and colipase activities paralleled that in the rate of lipase synthesis when rats were fed on isoenergetic diets containing increasing amounts (100-300 g/kg) of lipids (Wicker \& Puigserver, 1987), as well as in the early days of consumption of a $250 \mathrm{~g} \mathrm{lipid} / \mathrm{kg}$ diet (Wicker \& Puigserver, $1989,1990 \mathrm{~b}$ ). The ingestion of dietary lipids also resulted in lipase (Fig. 2) and, to a lesser extent, in colipase mRNA accumulation (Wicker et al. 1988; Wicker \& Puigserver, $1990 a$ ). To understand the mechanisms underlying lipase messenger accumulation, gene transcription measurements were carried out on isolated nuclei (Wicker \& Puigserver, $1990 b$ ). The enhanced transcription of lipase was found to be responsible for the increase in both enzyme activity and specific messenger levels in the pancreatic tissue of rats 


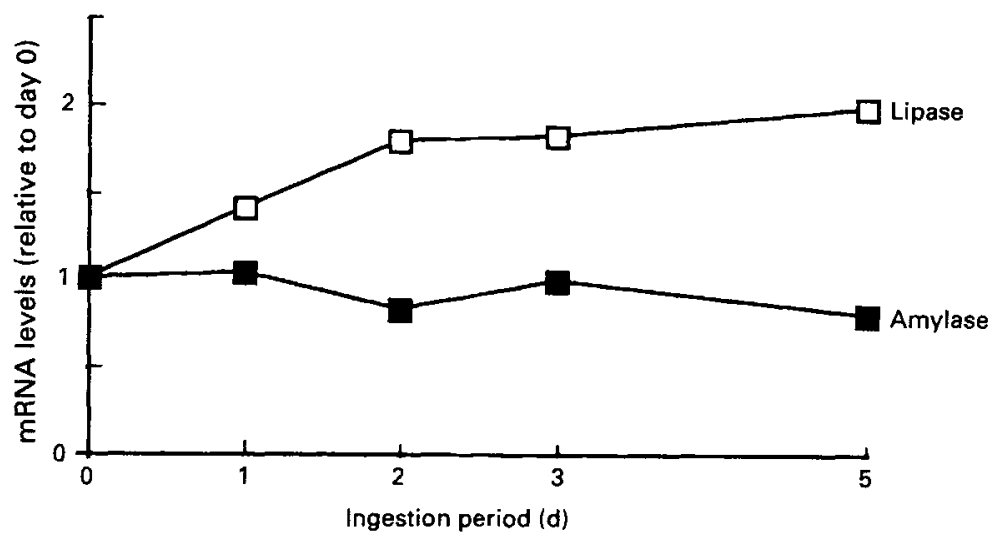

Fig. 2. Effects of a $250 \mathrm{~g}$ lipid $/ \mathrm{kg}$ diet on mRNA levels of lipase $(E C 3.1 .1 .3 ; \square)$ and amylase $(E C 3.2 .1 .1 ; \mathrm{w})$ as a function of the ingestion period.

adapted to a lipid-rich diet. At the same time, the amylase transcription rate was inhibited by the lipid-rich diet to an extent similar to that of its messenger decay (Wicker \& Puigserver, 1990b) and that of its relative synthesis (Wicker \& Puigserver, 1987), which once more suggests the existence of a transcriptional regulation of the expression of the amylase gene.

\section{CONCLUSION}

The mechanism whereby the biosynthesis of pancreatic secretory proteins is regulated either during ontogenesis or in response to dietary substrates is certainly a complex one. Multilevel regulation of almost each pancreatic enzyme occurs and involves changes in the rate of gene transcription, the efficiency of mRNA translation, and the stability of the mature primary transcript. Moreover, the existence of distinct gene expression profiles depending on the enzyme strongly suggests that each gene is regulated more or less independently. Last, on the basis of findings obtained using protein-free diets in particular, it seems likely that the specific activity and synthesis of a number of serine proteases, namely the isozyme forms of chymotrypsinogen and trypsinogen, may not be regulated in direct proportion to the level of protein substrates in the diet.

All in all, however, these arguments do not necessarily conflict with the idea that a coordinated regulation of most pancreatic enzymes may occur under usual physiological conditions. This control is thought to be mediated, at least partly, by gut regulatory peptides. Therefore, the regulation of pancreatic enzymes is presumably indirectly exerted by nutrients. However, the possibility that nutrients may have direct effects cannot be ruled out since, for instance, the changes in the mRNA levels of rat pancreatic lipase in the early days of consumption of a high-lipid diet involve a two-step mechanism: an early transient step under the direct action of the nutrient, and a delayed effect in which hormonal factors are probably involved. The use of cultured pancreatic cells is certainly a useful approach for discriminating between the direct and indirect effects of nutrients and hormones.

The fact that opposite responses in the biosynthesis of anionic and cationic isozymes were observed, in spite of the fairly high degree of structural identity between the 
corresponding genes, clearly indicates that the regulation of digestive enzyme synthesis in the pancreas and the underlying molecular mechanisms are still far from having been completely elucidated.

\section{REFERENCES}

Bazin, R., Lavau, M. \& Herzog, J. (1978). Pancreatic lipase and ketogenic conditions. Biomedicine 28, 160-165.

Ben Abdeljlil, A. \& Desnuelle, P. (1964). Sur l'adaptation des enzymes exocrines du pancréas à la composition du régime (The adaptation of the exocrine enzymes of rat pancreas to the composition of the diet). Biochemica et Biophysica Acta 81, 136-149.

Ben Abdeljili, A., Visani, A. M. \& Desnuelle, P. (1963). Adaptation of the exocrine secretion of rat pancreas to the composition of the diet. Biochemical and Biophysical Research Communications 10, 112-116.

Boulet, A. M., Erwin, C. R. \& Rutter, W. J. (1986). Cell-specific enhancers in the rat exocrine pancreas. Proceedings of the National Academy of Sciences, U.S.A. 83, 3599-3603.

Brannon, P. M. (1990). Adaptation of the exocrine pancreas to diet. Annual Review of Nutrition 10, 85-105.

Clauser, E., Gardell, S. J., Craik, C. S., MacDonald, R. J. \& Rutter, W. J. (1988). Structural characterization of the rat carboxypeptidase $A 1$ and $B$ genes. Comparative analysis of the rat carboxypeptidase gene family. Journal of Biological Chemistry 263, 17837-17845.

Corring, T. (1977). Possible role of hydrolysis products of the dietary components in the mechanisms of the exocrine pancreatic adaptation to the diet. World Review of Nutrition and Dietetics 27, 132-144.

Corring, T. \& Aumaître, A. (1970). Mise en place et évolution de l'équipement enzymatique du pancréas exocrine du jeune rat pendant la période embryonnaire, l'allaitement et le sevrage (Formation and development of the enzyme apparatus of the exocrine pancreas of young rats in the embryonic stage and during the sucking and weaning periods). Annales de Biologie Animale Biochimie Biophysique 10, 431-441.

Corring, T., Aumaitre, A. \& Durand, G. (1978). Development of digestive enzymes in the piglet from birth to 8 weeks. I. Pancreas and pancreatic enzymes. Nutrition and Metabolism 22, 231-243.

Corring, T., Calmes, R., Rérat, A. \& Gueugneau, A. M. (1984). Effets de l'alimentation protéiprive à court terme sur lá sécrétion d'azote endogène: sécrétion pancréatique exocrine chez le porc (Effect of short term feeding of a protein-free diet on endogenous nitrogen secretion: exocrine pancreas secretion in the pig). Reproduction, Nutrition, Développement 24, 495-506.

Corring, T., Juste, C. \& Lhoste, E. F. (1989). Nutritional regulation of pancreatic and biliary secretions. Nutrition Research Reviews 2, 161-180.

Dakka, N., Puigserver, A. \& Wicker, C. (1990). Regulation by a protein-free carbohydrate-rich diet of rat pancreatic mRNAs encoding trypsin and elastase isoenzymes. Biochemical Journal 268, 471-474.

Dakka, N., Wicker, C. \& Puigserver, A. (1988). Specific response of serine protease mRNA to a protein-free diet in the rat pancreas. European Journal of Biochemistry 176, 231-236.

Davicco, M. J., Le Faivre, J. \& Barlet, J. P. (1980). The endocrine regulation of exocrine pancreas in preruminant milk-fed calves. Annales de Recherches Vétérinaires 11, 123-132.

Deschodt-Lanckman, M., Robberecht, P., Camus, J. \& Christophe, J. (1971). Short-term adaptation of pancreatic hydrolases to nutritional and physiological stimuli in adult rats. Biochimie 53, 789-796.

Gardell, S. J., Craik, C. S., Clauser, E., Goldsmith, E. J., Stewart, C. B., Graf, M. \& Rutter, W. J. (1988). A novel rat carboxypeptidase, CPA2: Characterization, molecular cloning, and evolutionary implications on substrate specificity in the carboxypeptidase gene family. Journal of Biological Chemistry 263, 17828-17836.

Giorgi, D., Bernard, J. P., Lapointe, R. \& Dagorn, J. C. (1984). Regulation of amylase messenger RNA concentration in rat pancreas by food content. EMBO Journal 3, 1521-1524.

Giorgi, D., Renaud, W., Bernard, J. P. \& Dagorn, J. C. (1985). Regulation of proteolytic enzyme activities and mRNA concentrations in rat pancreas by food content. Biochemical and Biophysical Research Communications 127, 937-942.

Girard-Globa, A. \& Simond-Cote, E. (1977). Nutritional and circadian variations in lipase activity and colipase saturation in rat pancreas. Annales de Biologie Animale Biochimie Biophysique 17, 539-542.

Guilloteau, P., Le Huërou-Luron, I., Chayvialle, J. A., Mouats, A., Bernard, C., Cuber, J. C., Burton, J., Puigserver, A. \& Toullec, R. (1992). Plasma and tissue levels of digestive regulatory peptides during postnatal development and weaning in the calf. Reproduction, Nutrition, Development 32, 285-296.

Han, J. H., Rall, L. \& Rutter, W. J. (1986). Selective expression of rat pancreatic genes during embryonic development. Proceedings of the National Academy of Sciences, U.S.A. 83, 110-114. 
Harding, J. D., MacDonald, R. J., Przybyla, A. E., Chirgwin, J. M., Pictet, R. L. \& Rutter, W. J. (1977). Changes in the frequency of specific transcripts during development of the pancreas. Journal of Biological Chemistry 252, 7391-7397.

Henning, S. J. (1987). Functional development of the gastrointestinal tract. In Physiology of the Gastrointestinal Tract, 2nd ed., pp. 285-300 [L. R. Johnson, editor]. New York: Raven Press.

Howard, F. \& Yudkin, J. (1963). Effect of dietary change upon amylase and trypsin activities of the rat pancreas. British Journal of Nutrition 17, 281-294.

Howard, G., Keller, P. R., Johnson, T. M. \& Meisler, M. H. (1989). Binding of a pancreatic nuclear protein is correlated with amylase enhancer activity. Nucleic Acids Research 17, 8185-8195.

Iovanna, J. L., Dusetti, N., Cadenas, B. \& Calvo, E. L. (1990). Changes in growth and pancreatic mRNA concentrations during postnatal development of rat pancreas. Pancreas 5, 421-426.

Johnson, A., Hurwitz, R. \& Kretchmer, N. (1977). Adaptation of rat pancreatic amylase and chymotrypsinogen to changes in diet. Journal of Nutrition 107, 87-96.

Kawashima, I., Tani, T., Shimoda, K. \& Takiguchi, Y. (1987). Characterization of pancreatic elastase II cDNAs: Two elastase II mRNAs are expressed in human pancreas. DNA 6, 163-172.

Keller, S. A., Rosenberg, M. P., Johnson, T. M., Howard, G. \& Meisler, M. H. (1990). Regulation of amylase gene expression in diabetic mice is mediated by a cis-acting upstream element close to the pancreas-specific enhancer. Gene and Development 4, 1316-1321.

Kern, H. F., Rausch, U. \& Scheele, G. (1987). Regulation of gene expression in pancreatic adaptation to nutritional substrates or hormones. Gut 28, 89-94.

Lavau, M., Bazin, R. \& Herzog, J. (1974). Comparative effects of oral and parenteral feeding on pancreatic enzymes in the rat. Journal of Nutrition 104, 1432-1437.

Le Huërou, I., Guilloteau, P., Toullec, R., Puigserver, A. \& Wicker, C. (1991). Cloning and nucleotide sequence of a bovine pancreatic preprocarboxypeptidase A cDNA. Biochemical and Biophysical Research Communications 175, 110-116.

Le Huërou, I., Wicker, C., Guilloteau, P., Toullec, R. \& Puigserver, A. (1990a). Isolation and nucleotide sequence of cDNA clone for bovine pancreatic anionic trypsinogen. Structural identity within the trypsin family. European Journal of Biochemistry 193, 767-773.

Le Huërou, I., Wicker, C., Guilloteau, P., Toullec, R. \& Puigserver, A. (1990b). Specific regulation of the gene expression of some pancreatic enzymes during postnatal development and weaning in the calf. Biochimica et Biophysica Acta 1048, 257-264.

Le Huërou-Luron, I., Guilloteau, P., Wicker-Planquart, C., Chayvialle, J, A., Burton, J., Mouats, A., Toullec, R. \& Puigserver, A. (1992). Gastric and pancreatic enzyme activities and their relationship with some gut regulatory peptides during postnatal development and weaning in calves. Journal of Nutrition 122 , $1434-1445$.

Le Meuth, V., Farjaudon, N., Bawab, W., Chastre, E., Rosselin, G., Guilloteau, P. \& Gespach, C. (1991). Characterization of binding sites for VIP-related peptides and activation of adenylate cyclase in developing pancreas. American Journal of Physiology 260, G265-G274.

Le Meuth, V., Philouze, V., Formal, M., Le Huërou-Luron, I., Vaysse, N., Gespach, C., Guilloteau, P. \& Fourmy, D. (1992). Pharmacological and biochemical evidence for differential expression of A- and B-subtype CCK/gastrin receptors in the calf pancreas during development. Proceedings of the Nutrition Society 52, 170A.

Lhoste, E. F., Fiszlewicz, M., Gueugneau, A. M., Wicker-Planquart, C., Puigserver, A. \& Corring, T. (1993). Effects of dietary proteins on some pancreatic mRNAs encoding digestive enzymes in the pig. Jounal of Nutritional Biochemistry 4, 143-152.

Logsdon, C. D., Akana, S. F., Meyer, C., Dallman, M. F. \& Williams, J. A. (1987). Pancreatic acinar cell amylase gene expression: Selective effects of adrenalectomy and corticosterone replacement. Endocrinology 121, 1242-1250.

MacDonald, R. J., Stary, S. J. \& Swift, G. H. (1982a). Two similar but nonallelic rat pancreatic trypsinogens. Journal of Biological Chemistry 257, 9724-9732.

MacDonald, R. J., Swift, G. H., Quinto, C., Swain, W., Pictet, R. L., Nikovits, W. \& Rutter, W. J. (1982b). Primary structure of two distinct rat pancreatic proelastases determined by sequence analysis of the complete cloned messenger ribonucleic acid sequences. Biochemistry 21, 1453-1463.

Mourot, J. \& Corring, T. (1979). Adaptation of the lipase-colipase system to dietary lipid content in pig pancreatic tissue. Annales de Biologie Animale Biochimie Biophysique 19, 119-124.

Osborn, L., Rosenberg, M. P., Keller, S. A. \& Meisler, M. H. (1987). Tissue-specific and insulin-dependent expression of the amylase gene in transgenic mice. Molecular and Cellular Biology 7, 326-334. 
Pascual, R., Vendrell, J., Avilés, F. X., Bonicel, J., Wicker, C. \& Puigserver, A. (1990). Autolysis of proproteinase $\mathrm{E}$ in bovine procarboxypeptidase A ternary complex gives rise to subunit III. FEBS Letters 277, 37-41.

Pictet, R. L., Clark, W. R., Williams, R. H. \& Rutter, W. J. (1972). An ultrastructural analysis of the developing embryonic pancreas. Developmental Biology 29, 436-467.

Pierzynowski, S. G., Hakansson, H., Ljunggren, L., Martensson, L. \& Olsson, L. (1990). Portable closed loop feedback system for control of the blood glucose level in the pig. Artificial Organs 14, 118-129.

Pinsky, S. D., LaForge, K. S. \& Scheele, G. (1985). Differential regulation of trypsinogen mRNA translation: Full-length mRNA sequences encoding two oppositely charged trypsinogen isoenzymes in the dog pancreas. Molecular and Cellular Biology 5, 2669-2676.

Pond, W. G., Snook, J. T., McNeill, D., Snyder, W. I. \& Stillings, B. R. (1971). Pancreatic enzyme activities of pigs up to three weeks of age. Journal of Animal Science 33, 1270-1273.

Poort, S. R. \& Poort, C. (1981). Effect of feeding diets of different composition on the protein synthesis pattern of the rat pancreas. Journal of Nutrition 111, 1475-1479.

Puigserver, A., Wicker, C. \& Gaucher, C. (1986). Adaptation of pancreatic and intestinal hydrolases to dietary changes. In Molecular and Cellular Basis of Digestion, pp. 113-124 [P. Desnuelle, H. Sjöström and O. Noren, editors]. Amsterdam: Elsevier Science Publishers B.V., Biomedical Division.

Reboud, J. P., Marchis-Mouren, G., Pasero, L., Cozzone, A. \& Desnuelle, P. (1966). Adaptation de la vitesse de biosynthèse de l'amylase pancréatique et du chymotrypsinogène à des régimes riches en amidon ou en protéines (Adaptation of the rate of biosynthesis of pancreatic amylase and chymotrypsinogen to starch-rich or protein-rich diets). Biochimica et Biophysica Acta 117, 351-367.

Reboud, J. P., Pasero, L. \& Desnuelle, P. (1964). On chymotrypsinogen and trypsinogen biosynthesis by pancreas of rats fed on a starch-rich diet or a casein-rich diet. Biochemical and Biophysical Research Communications 17, 347-351.

Robberecht, P., Deschodt-Lankman, M., Camus, J., Bruylands, J. \& Christophe, J. (1971). Rat pancreatic hydrolases from birth to weaning and dietary adaptation after weaning. American Journal of Physiology 221, 376-381.

Ruckebusch, Y., Dardillat, C. \& Guilloteau, P. (1983). Development of digestive functions in the newborn ruminant. Annales de Recherches Vétérinaires 14, 360-374.

Rutter, W. J., Kemp, J. D., Bradshaw, W. S., Clark, W. R., Ronzio, R. A. \& Sanders, T. G. (1968). Regulation of specific protein synthesis in cytodifferentiation. Journal of Cellular Physiology 72, Suppl. 1, 1-18.

Sabb, J. E., Godfrey, P. M. \& Brannon, P. M. (1986). Adaptive response of rat pancreatic lipase to dietary fat: Effects of amount and type of fat. Journal of Nutrition 116, 892-899.

Samuelson, L. C., Keller, P. R., Darlington, G. J. \& Meisler, M. H. (1988). Glucocorticoid and developmental regulation of amylase mRNAs in mouse liver cells. Molecular and Cellular Biology 8, 3857-3863.

Saraux, B. \& Girard-Globa, A. (1982). Development of pancreatic enzymes in fetal and suckling rats with emphasis on lipase and colipase. Journal of Developmental Physiology 4, 121-137.

Saraux, B., Girard-Globa, A., Ouagued, M. \& Vacher, D. (1982). Response to the exocrine pancreas to quantitative and qualitative variations in dietary lipids. American Journal of Physiology 243, G10-G15.

Schick, J., Verspohl, R., Kern, H. \& Scheele, G. (1984). Two distinct adaptive responses in the synthesis of exocrine pancreatic enzymes to inverse changes in protein and carbohydrate in the diet. American Journal of Physiology 247, G611-G616.

Schmid, R. M. \& Meisler, M. H. (1992). Dietary regulation of pancreatic amylase in transgenic mice is mediated by a 126-base pair DNA fragment. American Journal of Physiology 262, G971-G976.

Simoes-Nunes, C. (1986). Adaptation of pancreatic lipase to the amount and nature of dietary lipids in the growing pig. Reproduction, Nutrition, Développement 26, 1273-1280.

Snook, J. T. (1965). Dietary regulation of pancreatic enzyme synthesis, secretion and inactivation in the rat. Journal of Nutrition 87, 297-305.

Stevenson, B. J., Hagenbüchle, O. \& Wellauer, P. K. (1986). Sequence organisation and transcriptional regulation of the mouse elastase II and trypsin genes. Nucleic Acids Research 14, 8307-8330.

Stratowa, C. \& Rutter, W. J. (1986). Selective regulation of trypsin gene expression by calcium and by glucose starvation in a rat exocrine pancreas cell line. Proceedings of the National Academy of Sciences, U.S.A. 83, 4292-4296.

Swift, G. H., Hammer, R. E., MacDonald, R. J. \& Brinster, R. L. (1984). Tissue-specific expression of the rat pancreatic elastase I gene in transgenic mice. Cell 38, 639-646. 
Takeuchi, T., Ogawa, M. \& Sugimura, T. (1977). Effects of various hormones and adrenalectomy on the levels of amylase in tat pancreas and parotid gland. Experientia 66, 1531-1532.

Temler, R. S., Dormond, C. A., Simon, E., Morel, B. \& Mettraux, C. (1984). Response of rat pancreatic proteases to dietary proteins, their hydrolysates and soybean trypsin inhibitor. Journal of Nutrition 114, $270-278$.

Track, N. S., Bockermann, M., Creutzfeldt, C., Schmidt, H. \& Creutzfeldt, W. (1972). Enzymatic and ultrastructural development of bovine exocrine panćreas. Comparative Biochemistry and Physiology 43, 313-322.

Van Nest, G. A., MacDonald, R. J., Roman, R. K. \& Rutter, W. J. (1980). Proteins synthetized and secreted during rat pancreatic development. Journal of Cell Biology 86, 784-794.

Vandermeers-Piret, M. C., Vandermeers, A., Wijns, W., Rathe, J. \& Christophe, J. (1977). Lack of adaptation of pancreatic colipase in rats and mice. American Journal of Physiology 232, E131-E135.

Walker, M. D., Edlund, T., Boulet, A. M. \& Rutter, W. J. (1983). Cell-specific expression controlled by the 5 '-flanking region of insulin and chymotrypsin genes. Nature 306, 557-561.

Wicker, C. \& Puigserver, A. (1987). Effects of some inverse changes in dietary lipid and carbohydrate on the synthesis of some pancreatic secretory proteins. European Journal of Biochemistry 162, 25-30.

Wicker, C. \& Puigserver, A. (1989). Changes in mRNA levels of rat pancreatic lipase in the early days of consumption of a high-lipid diet. European Journal of Biochemistry 180, 563-567.

Wicker, C. \& Puigserver, A. (1990a). Rat pancreatic colipase mRNA: Nucleotide sequence of a cDNA clone and nutritional regulation by a lipidic diet. Biochemical and Biophysical Research Communications 167, 130-136.

Wicker, C. \& Puigserver, A. (1990b). Expression of a rat pancreatic lipase gene is modulated by a lipid-rich diet at a transcriptional level. Biochemical and Biophysical Research Communications 166, 358-364.

Wicker, C., Puigserver, A. \& Scheele, G. (1984). Dietary regulation of levels of active mRNA coding for amylase and serine protease zymogens in the rat pancreas. European Journal of Biochemistry 139, 381-387.

Wicker, C., Scheele, G. \& Puigserver, A. (1983). Adaptation au régime alimentaire du niveau des ARNm codant pour l'amylase et les protéases à sérine pancréatiques chez le rat (Dietary adaptation of levels of mRNA coding for pancreatic amylase and serine proteases in the rat). Compte Rendu de l'Académie des Sciences de Paris, Série D Sciences Naturelles 297, 281-284.

Wicker, C., Scheele, G. A. \& Puigserver, A. (1988). Pancreatic adaptation to dietary lipids is mediated by changes in lipase mRNA. Biochimie 70, 1277-1283.

Wicker-Planquart, C. \& Puigserver, A. (1992). Primary structure of rat pancreatic lipase mRNA. FEBS Letters 296, 61-66. 